\title{
Editorial
}

\section{Normal as Usual? Human Rights in Times of COVID-19}

When we started drafting this editorial note, the coronavirus had not yet become a global threat. Our initial plan was to use this note to remind readers of the 5oth anniversary in December 2019 of Greece's withdrawal from the Council of Europe. Withdrawing was a means for the dictators who ruled Greece at that time to avoid the embarrassment of the impending expulsion of Greece from the Council of Europe in the aftermath of the emblematic Greek case. ${ }^{1}$ We would then connect the dots between this instance in the history of the Council of Europe and the recent emergence of illiberal democracies in Europe. Our ambition was to ask how the Council of Europe can rise to this new challenge and use its multifaceted apparatus effectively to react and possibly to sanction this alarming phenomenon. The two thought-provoking guest editorial notes by Professor Wolfgang Benedek and Judge Ineta Ziemele that we have the privilege to publish in this issue treat this question in some detail.

The pandemic obliged us essentially to rewrite this editorial note. Evidently, this is a truly minor inconvenience compared with the impact that the pandemic has had - and continues to have - on people's everyday lives or on the global economy, and with the feeling of vulnerability and fragility with which COVID-19 has endowed humanity. Emergencies call for extraordinary measures. Inevitably, such measures interfere with human rights. Some of these interferences are direct, thus also easier to recognise. For instance, lockdown policies clash with and restrict a number of fundamental liberties. Other types

1 The Greek Case (Denmark, Norway, Sweden and The Netherlands v Greece) App nos 3321/67, $3322 / 67,3323 / 67,3344 / 67$ (ECmHR, 05 November 1969, report). For an overview, see J Becket, 'The Greek Case Before the European Human Rights Commission' (1970) Human Rights 91. 
of intersections between the pandemic and human rights are rather indirect. This makes it more difficult to assess the damage they (will) cause. For instance, it is certain that the impact of the pandemic on the economy will inevitably limit the ability of states to engage with human rights protection policies having a (significant) economic cost. To give an example, to run a wellequipped public hospital, national authorities rely on public revenues coming from taxes. Decline in the economy also amounts to reduction of resources that can be spent on positive human rights obligations such as provision of medical care. Obviously, this is also a matter of priorities (which is a question we discuss further below), meaning that a state may decide to use its limited resources to run a hospital to satisfactory standards. But the money spent on this policy will not be available for another human rights relevant policy, such as the protection of asylum seekers and refugees or running a well-funded prison system. On a number of occasions, the European Court of Human Rights (ECtHR) declared that limited resources cannot excuse the violation of rights such as the ones enshrined in Articles $3^{2}$ or $6^{3}$ ECHR. However, states are making difficult choices and the Court cannot ignore the new reality affected by a very plausible economic downfall caused by the CoviD-19 pandemic.

As we write this note, we do not yet know if and when the pandemic emergency will end and what the post-Covid reality will look like. We are also unsure as to which of the changes that governments and their societies have urgently adopted to cope with covid-19 will outlive the pandemic. What we know with certainty is that these changes and, more generally, emergency measures against the pandemic in Europe raise abundant human rights questions that national courts, first, and the ECtHR, subsequently, will be called on to scrutinise. To some extent, the outcome of a particular human rights case depends on the specifics of each particular application. Therefore, attempting to predict the impact of the pandemic on specific rights or assess in abstract terms the lawfulness of measures against COVID-19 would be a rather futile exercise. Instead, in the text that follows we are making a few selected points concerning more generic and theoretical human rights questions raised by the pandemic. These are all questions that a court like the ECtHR, one way or another, will have to engage with and that authors (publishing with The European Convention of Human Rights Law Review) are warmly invited to explore.

The first point concerns prioritisation and self-restraint. Human rights law interpretation has never been a dry mechanical exercise. It very often involves tragical (in a Hegelian sense) dilemmas between conflicting 'goods' and in

2 See, for example, Dankevich v. Ukraine App no 40679/98 (ECtHR, 29 April 2003), para 144.

3 See, for example, Prodan v. Moldova App no 49806/99 (ECtHR, 18 May 2004), para 53. 
particular legitimate goals, each one of which tries to prevail. Due to their urgency and intensity, emergencies often magnify these dilemmas. A simple example in the context of COVID-19 is the dilemma related to lockdown policies. On the one hand, lockdown policies are lowering significantly the risk of the spreading of the virus. This way, they enhance the protection of life and health. On the other hand, they are poisonous, inter alia, for the economy. This affects individual prosperity, but - as already explained - also the ability of public authorities effectively to protect human rights through positive actions. The dilemma between lockdown and the economy is a very tangible trade-off that can easily be translated into a catchy and polarising political dichotomy reflected in the positions of political parties wishing to win the elections. The obvious risk for courts tackling this dilemma is judicial politicisation. The judges of a court might genuinely strive to put their political preferences aside when deciding a case. However, even in this case, the priorities they set with their case law or the way they strike the balance between the conflicting aims, values or rights, inevitably reflects their ideology and inclinations. Judgments are not made in a vacuum and judges are affected by real life events, such as the pandemic. One possible way of limiting personal biases is judicial selfrestraint. In the ECHR context, this means that the Court will need to give states a fairly broad margin of appreciation while testing the legitimacy of the goals pursued by a given policy against the pandemic. However, judicial selfrestraint comes with a cost. A difficult balance ought to be maintained to avoid undermining the ECHR's raison d'être, given also that the most flagrant human right violations can happen during emergencies. While one needs to understand that the authorities are under a lot of pressure, one should not forget that the impact of the state policies can have a disproportionate impact on human rights. This is when the Court's interference is particularly necessary. It is quite a task to ensure that states honour human rights in normal circumstances, and it is much more difficult to do that during a crisis. Although selfrestraint can be a tempting option, too much self-restraint might make a court irrelevant. Yet, if self-restraint is a path a court does not wish to walk, it will need to meticulously build the grounds of legitimacy of its decisions. This requires putting an extra effort in showing that the priorities a court establishes do not reflect mere political preferences.

Unlike the first point, which primarily concerns the constitutional dimension of the work of the ECtHR, the second pertains to its role as an international court and in particular subsidiarity. In theory, this somewhat controversial concept can help the ECtHR to maintain a balance between, on the one hand, respect for national decision-making through deference to the national authorities and, on the other hand, effective human rights protection through, 
inter alia, the establishment of common human rights standards applicable across the entire European continent. In practice, however, the limits of subsidiarity are vague. Subsidiarity is often difficult to test and the Court often ends up without clear guidance as to what its subsidiary role entails. That said, not all aspects of subsidiarity are so unclear and open to a variety of interpretations. It has been argued that subsidiarity can be divided into 'substantive' and 'procedural.' 4 Substantive subsidiarity means that the Court cannot just second-guess the decisions of national authorities, but it should seriously take them into account. Procedural subsidiarity only refers to the fact that the ECtHR comes to the scene only when the national courts had a chance to deal with an alleged human rights violation. The procedural dimension of subsidiarity is of particular relevance here. In emergency circumstances, the Court's subsidiarity role - in the sense of inability of impacting the ongoing human rights issues - is both a strength and a weakness of the system. Its weakness is obvious. Undoubtedly, the majority of COVID-19 related cases will be dealt with on the national level. This is not merely a consequence of the exhaustion of domestic remedies admissibility requirement. It naturally flows from the extraordinary nature of the measures against CoviD-19. Emergency measures are rapid responses to a threat that may severely undermine human rights. Affected persons will first seek redress before national courts. With the exception of interim measures under Rule 39 of the Rules of Court (which are rare), the chances are that by the time the ECtHR examines a claim concerning extraordinary measures against the pandemic, many of the measures at issue will have fully produced their effects and (possibly) ended. The ECtHR case law against such measures will still have a 'pedagogical' value and will contribute to the ECHR acquis that all states will have to consider and comply with in future emergencies. However, in principle, ceasing ongoing violations of the ECHR, remedying wrongs or 'fine-tuning' emergency measures so that they do not cause more harm than what is necessary will rest with national authorities, the role of which in the context of emergencies is of crucial importance. In the case of emergencies, the ECtHR is a second-order, post facto defence. As the flip side of the same coin, this subsidiarity can be seen as a strength of the system. Although it is unable to impact the ongoing crisis directly, the ECtHR can still act as a deterrent; the authorities know that their actions will be scrutinised by the Court in the future. It is disputable how effective this

4 See, F de Londras and K Dzehtsiarou, Great Debates on the European Convention on Human Rights (Palgrave 2018), 9. 
deterrence is but the 'shadow' of the Court should always be in the mind of national decision-makers and judges.

The third point concerns the idiosyncrasy of the COvID-19 emergency and its comparability with other emergencies that the ECtHR has dealt with in the past. The ECtHR has not decided cases concerning health emergencies yet. As a result, there is no case law that can guide the authorities as to the appropriateness of measures to be adopted during such emergencies. Many commentators tried to use the case law on military emergencies to infer standards that would be transferrable to the health emergency triggered by the COVID-19 pandemic. One might suggest that the nature and the spread of health and military emergencies are different and therefore the approach to these two types of emergencies should differ. The military emergencies that happened in Europe after World War II were less widespread and triggered different sorts of state measures. That being explained, a question to ask is whether the Court will need to develop a brand-new set of standards in response to the ongoing health emergency. In that respect, we think that it is important to recognise the unique character of the CoviD-19 emergency, inter alia, because transferring rules and regulations from military emergencies onto a health emergency may have two cumulative, negative consequences. First, sticking to the extraordinary measures traditionally adopted for other than the pandemic types of emergency will prevent national authorities from reacting appropriately to the challenges of the present health emergency. Extraordinary measures need to be fit for purpose. For instance, it is unlikely that the extensive lockdown would be justified under a military emergency; however, a lockdown policy might be justified under a health emergency. Second, mutatis mutandis, the measures that are permissible under a military emergency might be completely inappropriate during a health emergency. If the measures are different, the effects, approaches and consequences of emergency regulations should also be clearly separated. Yet, one must admit that each crisis, irrespective of its causes, has its own unique features that invite assessment of the individual circumstances.

As to the fourth point made in this note, among the hottest academic discussions during the first weeks of the pandemic was a discussion about the desirability of derogations under Article 15 of the European Convention. There were effectively two competing views. Some commentators opined that states should have derogated from the ECHR (and other international human rights instruments) because such derogations will effectively quarantine the emergency measures. The logic behind this approach is that, as soon as the emergency is over, the derogation will be lifted, and the law will revert back 
to normal. ${ }^{5}$ Other commentators point out that such derogations are neither necessary nor desirable. According to them, the Convention has a mechanism of natural accommodation of emergencies such as the covid-19 crisis and states shall act within their margin of appreciation, which can be broader than usual due to the magnitude of the crisis. Moreover, when the crisis is over, the scope of the margin will go back to normal, providing a 'natural' quarantining effect. ${ }^{6}$ The coviD-19 crisis offers fertile ground to test both approaches. A significant proportion of the contracting states has derogated from the Convention. ${ }^{7}$ However, the majority of the states have not. In the years to come, two key questions will need to be considered. First, it will be important to see if the formal derogation from the Convention has had any practical effect on the scope of protected rights and whether this derogation generated a quarantining effect as is predicted by the proponents of derogations. Second, in the years to come we will find out if the ECtHR is going to treat those states which formally derogated any differently to those which did not. Whilst it is true that the current pandemic is not the only pandemic humankind has ever suffered, the coronavirus emergency is the first one to occur in a period of human history where human rights play such a primordial role in public discourse and, most importantly, as a constitutive ingredient of the 'social contract', rule of law and checks and balances within liberal democracies.

This creates certain expectations concerning the weight that ought to be given to human rights and the way they can play within the pandemic emergency. Thus, to move to our fifth point, unlike other crises or emergencies, which only concern a small number of states or even just one polity and its society, the threat of COVID-19 is universal. But how is this observation linked with the expectations regarding the function of human rights? Responses against the pandemic must be balanced against human rights. Both 'elements' in this relationship (namely human rights and the emergency situation) are common to all liberal democracies, in particular within Europe. All the 47 Council of Europe member states share a common human rights locus, namely the text

5 See, for example, A Greene 'Derogating from the European Convention on Human Rights in Response to the Coronavirus Pandemic: If not Now, When?' (2020) (3) European Human Rights Law Review $262-276$.

6 See, for example, K Dzehtsiarou 'Article ${ }_{5}$ Derogations: Are They Really Necessary during the COVID-19 Pandemic?' (2020) European Human Rights Law Review (forthcoming).

7 Albania, Armenia, Estonia, Georgia, Latvia, North Macedonia, Moldova, Romania, San Marino, Serbia have derogated from the ECHR during the covid-19 pandemic. See: <https:// www.coe.int/en/web/conventions/full-list/-/conventions/treaty/005/declarations?p_auth= oCoowpDO>. 
of the ECHR and its rich interpretation by the ECtHR. If both the nature of the risk/threat of COVID-19, and (ECHR) human rights are common, it would not be unreasonable then to expect that a certain degree of consensus will emerge in the way states will ultimately use human rights law to 'tame' the extraordinary measures adopted to fight the pandemic. However, a number of factors mitigating the expectations regarding consensus and the role of human rights should be considered. First, one needs to take into account the points we made earlier in this note concerning judicial self-restraint and subsidiarity - in particular their impact on the ECtHR's decisions scrutinising the compliance of national measures against the pandemic with the Convention. Second, the margin of appreciation which states inherently enjoy regarding the measures they employ to achieve a goal of protection must also be considered. As is common knowledge, discretion is part and parcel of the principle of due diligence which applies in the case of positive (as opposed to negative) human rights obligations of protection. States are free to choose amongst different fit for purpose measures the ones they prefer to deploy as a means to pursue a goal of protection. Thus, whilst human rights are a common denominator, different states may choose to follow diverse paths and apply dissimilar strategies to respond to COVID-19. Pluralism is an impediment to consensus. In reality, although one can find some common trends in the behaviour of national authorities in Europe in dealing with the pandemic, the precise measures vary significantly, and consensus is perhaps possible only at a certain level of abstraction.

Moving to our sixth and final point, discretion regarding the means of protection is a feature of positive human rights obligations. The pandemic offers a fertile ground for deepening our knowledge about the classification between negative and positive obligations and can serve as a very interesting case study allowing us to revisit the rigidness of the distinction between said classes of obligations. Resorting again to the example of lockdown, this measure interferes with a number of rights. To name a few, states must refrain from prohibiting people from circulating freely, going to work, visiting family or getting married. The restrictions at issue are directly attributable to the state. Moreover, causality between state conduct and the result, i.e. the aforementioned human rights interferences, is evident. In a nutshell, the lockdown, a stateimposed measure, limits a number of freedoms. Prima facie, these limitations amount to negative human rights interferences, the lawfulness of which depends on proportionality and, in particular, on necessity. State conduct should not restrict qualified rights, unless and to the extent that compelling reasons make it necessary. However, the negative interferences at issue are the means 
to an end associated with human rights protection. Arguably, lockdown serves a protective purpose. It is a means to protect human life and health. Adopting a lockdown policy involves a risk assessment, which is an element of due diligence/positive human rights obligations. Through lockdown policies, states can argue that they comply with positive human rights obligations. Accordingly, the lawfulness of lockdown measures deployed for the purposes of human rights protection depends on subjective (as opposed to objective state responsibility for the breach of negative obligations) factors pertaining to positive human rights obligations, such as knowledge of the existence of a threat or the ability to act. That being explained, the question that begs an answer is whether negative human rights interferences for the purposes of protection from a threat (such as the pandemic) are the same and should be (judicially) treated as other negative human rights interference which do not pursue protective goals.

We conclude this editorial note with two final thoughts. The first concerns the question as to whether the pandemic should be seen as an opportunity for human rights law. No doubt, Covid-19 is a very painful experience, a gigantic threat and a genuine challenge for humankind. That said, and according to the old saying, every cloud has a silver lining. Admittedly, we are not ready to go as far as arguing that a tragedy, the pandemic, outside of a challenge, is also an opportunity for human rights. However, we do think that it can teach us much about human rights, their role, limits and modus operandi in emergencies. Undoubtedly, the ECtHR case law on health emergencies will be significantly expanded and the rules will become clearer should we ever face a similar challenge in the future. Second, to better explain the title of this note, emergencies are a rupture in 'normality'. They justify extraordinary measures. Because of their urgent and largely unforeseen nature, they prompt polities to press the 'pause button' and focus on the emergency as a matter of priority. But, whilst our globe has seemingly pressed this 'pause button', the brutal killing of a black person by police authorities in the United States and the reaction this event triggered $^{8}$ reminded us that the Covid-19 crisis is not the only human rights issue that must be dealt with. Life goes on. It does not entirely stop because of an emergency. In other words, the pandemic 'pause button' is not powerful enough to 'freeze' important social issues, such as the ones pertaining to systemic racism and police brutality. Pressing social demands concerning human rights and enduring injustice cannot wait. In that sense, the extraordinary

8 'George Floyd: What Happened in the Final Moments of His Life?' (ввс News): <https:// www.bbc.co.uk/news/world-us-canada-52861726>. 
nature of states of emergencies cannot and should not prevent human rights from performing their normal role in society, as usual.

\section{Vassilis P Tzevelekos}

Senior Lecturer in Law, University of Liverpool, Liverpool, United Kingdom v.tzevelekos@liverpool.ac.uk

\section{Kanstantsin Dzehtsiarou}

Professor in Human Rights Law, University of Liverpool, Liverpool, United Kingdom

k.dzehtsiarou@liverpool.ac.uk 